\title{
Pengaruh Diameter Stum Dan SP-36 Terhadap Pertumbuhan Bibit Karet (Hevea brasilliensis $\mathrm{M}$ )
}

\author{
Sumartoyo \\ Fakultas Pertanian Universitas Kapuas Sintang \\ email: lppmmartoyo@yahoo.co.id
}

\begin{abstract}
Abstrak: Karet (Hevea brassiliensis Muell. Arg) merupakan komoditas yang penting, karena merupakan sumber devisa bagi negara, penghasil bahan baku berbagai industri, dan dapat memperluas kesempatan kerja bagi penduduk di Indonesia umumnya dan kabupaten Sintang khususnya. Badan statistik kabupaten Sintang (2017:166) memaparkan bahwa sebanyak 27.767 kepala keluarga mata pencahariannya adalah dengan berkebun karet dengan total luas 84.930 ha, dari tolat luas tersebut 11.148 ha di antaranya kondisinya telah rusak dan perlu diremajakan. Supaya nantinya kebun karet yang diremajakan mempunyai produktifitas yang tinggi perlu disediakan bibit yang baik. Nazaruddin dan Paimin (2016:148-150) memaparkan bahwa bibit karet yang berkualitas dapat diproleh dengan penggunaan stum yang mempunyai diameter tidak terlalu kecil dan tidak terlalu besar disertai pemberian pupuk, antara lain SP-36. Penelitian ini bertujuan untuk mengetahui pengaruh kombinasi diameter stum dengan SP-36 terhadap pertumbuhan bibit karet, dan untuk mendapatkan kombinasi dari perlakuan diameter stum dengan SP-36 yang menghasilkan pertumbuhan bibit karet teringgi. Penelitian ini dirancang secara faktorial, terdiri dari dua faktor, dilaksanakan dengan menggunakan Rancangan Acak Kelompok Lengkap. Faktor pertama adalah diameter stum karet (D), terdiri dari 3 taraf, yaitu 1,0-1,4 $\mathrm{cm}\left(\mathrm{d}_{1}\right), 1,5-1,9$ $\mathrm{cm}\left(\mathrm{d}_{2}\right)$, dan 2,0-2,4 $\mathrm{cm} \quad\left(\mathrm{d}_{3}\right)$. Faktor ke dua adalah SP-36 $(\mathrm{S})$ terdiri dari 4 taraf dosis, yaitu tanpa sp-36 ( $\left.\mathrm{s}_{0}\right), 5,00 \mathrm{~g}$ per tanaman $\left(\mathrm{s}_{1}\right), 10,00 \mathrm{~g}$ per tanaman $\left(\mathrm{s}_{2}\right)$ dan 15,00 g per tanaman ( $\left.\mathrm{s}_{3}\right)$. Masing-masing kombinasi perlakuan diulang 3 kali. Pengamatan dikakukan terhadap peubah tinggi tunas dan diameter tunas. Hasil penelitian menunjukkan bahwa Interaksi antara diameter stum dengan SP-36 berpengaruh terhadap inggi tunas dan diameter tunas. Kombinasi diameter stum 1,50-1,90 $\left(\mathrm{d}_{2}\right)$ dangan SP-36 sebanyak 10,00 g per tanaman $\left(\mathrm{s}_{2}\right)$ menghasilkan pertumbuhan bibit karet tertinggi, pada kombinasi perlakuan tersebut menghasilkan tinggi tunas $25,18 \mathrm{~cm}$ dan diameter tunas 5,25 $\mathrm{mm}$.
\end{abstract}

Kata Kunci: Diameter Stum, SP-36, Pertumbuhan, Bibit Karet

\section{PENDAHULUAN}

Karet (Hevea brassiliensis Muell. Arg) merupakan komoditas yang baku berbagai industri, dan dapat penting, karena merupakan sumber devisa bagi negara, penghasil bahan 
Pengaruh Diameter Stum Dan SP-36 Terhadap Pertumbuhan Bibit Karet (Hevea brasilliensis $\mathrm{M}$ )

memperluas kesempatan kerja bagi penduduk di Indonesia umumnya dan kabupaten Sintang khususnya. Jutaan penduduk Indonesia mata pencahariannya tergantung pada tanaman ini (Supriyadi dan Nancy, 2001:385-397). Badan statistik kabupaten Sintang (2017:166) memaparkan bahwa sebanyak 27.767 kepala keluarga mata pencahariannya adalah dengan berkebun karet dengan total luas 84.930 ha, dari tolat luas tersebut 11.148 ha di antaranya kondisinya telah rusak dan perlu diremajakan. Supaya nantinya kebun karet yang diremajakan mempunyai produktifitas yang tinggi perlu disediakan bibit yang baik. Nazaruddin dan Paimin (2016:148150) memaparkan bahwa bibit karet yang berkualitas dapat diproleh dengan penggunaan stum yang mempunyai diameter tidak terlalu kecil dan tidak terlalu besar disertai pemberian pupuk, antara lain SP-36.

\section{METODOLOGI PENELITIAN}

Penelitian ini dilksanakan di desa Martiguna kecamatan Sintang kabpaten Sintang, sebagai media tanaman adalah tanah PMK. Alatalat yang digunakan: parang, cangkul, polybag, gergaji triplek, kayu, ayakan tanah, tali rafia, timbangan, jangka sorong, mini sprayer, meteran, dan kamera. Bahan bahan yang digunakan dalam penelitian ini adalah: SP-36, Urea, $\mathrm{KCl}$, stum tanaman karet dan air.

Penelitian ini dirancang secara faktorial, terdiri dari dua faktor, dilaksanakan dengan menggunakan Rancangan Acak Kelompok Lengkap. Faktor pertama adalah diameter stum karet (D), terdiri dari 3 taraf, yaitu $1,0-1,4 \mathrm{~cm}$ $\left(\mathrm{d}_{1}\right), 1,5-1,9 \mathrm{~cm}\left(\mathrm{~d}_{2}\right)$, dan 2,0-2,4 cm $\left(d_{3}\right)$. Faktor ke dua adalah SP-36 (S) terdiri dari 4 taraf dosis, yaitu tanpa sp-36 $\left(\mathrm{s}_{0}\right), 5,00 \mathrm{~g}$ per tanaman $\left(\mathrm{s}_{1}\right)$, $10,00 \mathrm{~g}$ per tanaman $\left(\mathrm{s}_{2}\right)$ dan $15,00 \mathrm{~g}$ per tanaman ( $\mathrm{s}_{3}$ ). Masing-masing kombinasi perlakuan diulang 3 kali. Pengamatan dikakukan terhadap peubah tinggi tunas dan diameter tunas.

Data yang diperoleh dihitung reratanya. Pemeriksan terhadap sarat syahnya analisis ragam dilakukan dengan uji Bartlet dan uji Tukey. Data dianalisis dengan sidik ragam 
dan dilanjutkan dengan uji BNJ pada taraf nyata 5\%. Model linier aditif yang dipostulatkan untuk menganalisis setiap peubah terikat yang diamati adalah $\mathrm{Y}_{\mathrm{ijk}}=\mu+\mathrm{A}_{\mathrm{i}}+$ $S_{j}+\beta_{k}+(A S)_{i j}+\varepsilon_{i j k}$

\section{HASIL PENELITIAN}

Hasil penelitian pengaruh perlakuan terhadap peubah yang diamati (tinggi tunas dan diameter tunas) disajikan pada Tabel 1

Tabel 1. Hasil Penelitian Pengaruh Perlakuan Terhadap Peubah Yang Diamati

\begin{tabular}{|c|c|c|c|c|c|}
\hline \multicolumn{3}{|c|}{ Tinggi tunas } & \multicolumn{3}{|c|}{ Dimeter tunas } \\
\hline Perlakuan & Nilai t & engah & Perlakuan & Nilai & tengah \\
\hline$d_{1} s_{0}$ & 15.30 & $\mathrm{a}$ & $d_{1} s_{0}$ & 4.15 & $\mathrm{a}$ \\
\hline$d_{1} \mathbf{s}_{2}$ & 17.05 & $\mathrm{a}$ & $\mathbf{d}_{1} \mathbf{S}_{2}$ & 4.22 & $\mathrm{a}$ \\
\hline$d_{1} s_{1}$ & 17.08 & $\mathrm{a}$ & $d_{1} s_{1}$ & 4.25 & $\mathrm{a}$ \\
\hline$d_{2} s_{0}$ & 17.40 & $\mathrm{a}$ & $d_{2} s_{0}$ & 4.37 & $a b$ \\
\hline$d_{1} S_{3}$ & 17.75 & $\mathrm{a}$ & $d_{1} s_{3}$ & 4.47 & $a b$ \\
\hline$d_{3} S_{0}$ & 20.27 & $\mathrm{a}$ & $d_{3} s_{0}$ & 4.78 & $\mathrm{ab}$ \\
\hline$d_{2} s_{1}$ & 20.92 & $\mathrm{a}$ & $d_{2} s_{1}$ & 5.27 & $\mathrm{~b}$ \\
\hline $\mathbf{d}_{2} \mathbf{s}_{2}$ & 27.18 & $\mathrm{~b}$ & $d_{2} \mathbf{S}_{2}$ & 5.45 & $\mathrm{c}$ \\
\hline $\mathbf{d}_{\mathbf{2}} \mathbf{S}_{3}$ & 27.90 & $\mathrm{bc}$ & $d_{2} s_{3}$ & 5.62 & $\mathrm{~cd}$ \\
\hline$d_{3} S_{1}$ & 28.03 & $\mathrm{bc}$ & $d_{3} s_{1}$ & 5.85 & de \\
\hline$d_{3} s_{2}$ & 31.10 & $\mathrm{~cd}$ & $d_{3} s_{2}$ & 5.93 & ef \\
\hline$d_{3} s_{3}$ & 35.25 & $\mathrm{~d}$ & $d_{3} S_{3}$ & 6.35 & $\mathrm{f}$ \\
\hline
\end{tabular}

SumbeR : Hasil analisis data, 2018

Ketrangan : Nilai rerata yang diikuti huruf beda berarti berbeda nyata

Hasil penelitian untuk peubah dengan SP-36 10,00 g per tanaman tinggi tunas maupun diameter tunas $\quad\left(\mathrm{d}_{2} \mathrm{~s}_{2}\right)$ menghasilkan tinggi tunas menunjukkan bahwa kombinasi mapun diameter tunas yang tidak perlakuan diameter stum 2,0-2,4 cm berbeda nyata dengan kombinasi 
Pengaruh Diameter Stum Dan SP-36 Terhadap Pertumbuhan Bibit Karet (Hevea brasilliensis $\mathrm{M}$ )

diameter stum yang lebih besar dan dosis SP-36 yang lebih tinggi $\left(\mathrm{d}_{2} \mathrm{~S}_{3}\right.$ $\begin{array}{llll}\mathrm{d}_{2} \mathrm{~s}_{3} & \text { dan } & \left.\mathrm{d}_{3} \mathrm{~s}_{3}\right) \text {. Kombinasi } & \mathrm{d}_{2} \mathrm{~s}_{2}\end{array}$ menghasilkan tinggi tunas tunas yang lebih tinggi dan diameter tunas yang lebih besar dibanding kombinasi diameter stum yang lebih kecil dan dosis SP-36 yang lebih rendah $\left(d_{1} p_{0}, d_{1} p_{2} \quad d_{1} p_{1} d_{2} p_{0}\right)$.

\section{PEMBAHASAN}

Hasil penelitian menunjukkan bahwa interaksi antara ukuran diameter stum dengan SP-36 berengaruh terhadap tinggi tunas dan diameter tunas. Terjadinya intraksi antara ukuran diameter stum dengan SP-36 terhadap peubah tinggi tunas dan diameter tunas dapat dijelaskan: Pada diameter stum yang makin besar menyimpan cadangan karbohidrat yang lebih banyak dari pada yang kecil. Suradinata (2015:17-27) menjelaskan bahwa komponen penyusun sel jaringan tumbuhan berkayu didominasi oleh karbohidrat. Karbohidrat didalamnya pada proses kelangsungan bibit dimetabolismekan, diubah ke bentuk lain diantaranya energi, yang selanjutnya digunakan untuk penumbuhan akar. Pada saat akar sudah terbentuk jika disekitarnya terdapat hara, maka tanaman akan mengambil hara tersebut.

Hasil penelitian menunjukkan bahwa kombinasi diametr stum 1,5$1,9 \mathrm{~cm}$ dengan $\mathrm{SP}-36 \quad 10,00 \mathrm{~g}$ pertannaman $\left(\mathrm{d}_{2} \mathrm{~S}_{2}\right)$ mengasilkan tinggi tunas dan diameter tunas yang tidak berbeda pada selang kepercayaan 95\% dengan kombinasi ukuran diameter stum yang lebih besar dengan dosis SP-36 yang lebih tinggi. Hal ini diduga diametr stum 1,5-1,9 cm telah cukup dalam penyediaan cadangan makanan / energi untuk pmbentukan akar, dan dosis SP-36 10,00 g per tanaman telah cukup untuk menyediakan hara $\mathrm{P}$ bagi bibit karet.

\section{KESIMPULAN DAN SARAN}

Hasil penelitian menunjukkan bahwa Interaksi antara diameter stum dengan SP-36 berpengaruh terhadap inggi tunas dan diameter tunas. Kombinasi diameter stum 1,50-1,90 $\left(\mathrm{d}_{2}\right)$ dangan SP-36 sebanyak 10,00 g 
Pengaruh Diameter Stum Dan SP-36 Terhadap Pertumbuhan Bibit Karet (Hevea brasilliensis $\mathrm{M}$ )

per tanaman $\left(\mathrm{s}_{2}\right)$ menghasilkan pertumbuhan bibit karet tertinggi, pada kombinasi perlakuan tersebut menghasilkan tinggi tunas $25,18 \mathrm{~cm}$ dan diameter tunas $5,52 \mathrm{~mm}$.

\section{DAFTAR PUSTAKA}

Badan Pusat Statistik Kabupaten Sintang 2017. Kabupaten Sintang Dalam Angka. Sintang: Badan Pusat Statistik Kabupaten Sintang.

Nazaruddin dan Painin, B. 2003. Budidaya Karet dan Strategi
Pemasarannya. Jakarta:

Penebar Swadaya,

Supriyadi and C. Nancy. 2001. "Accelerating rubber tecnology adoption in indonesian rubber smallholdings". In Procedings Indonesian Rubber Conference and IRRDB Symposium 2000. Indonesian Rubber Research Institute. Vol. II: 385-397.

Suradinata, T.S. 2015. Struktur Tumbuhan. Bandung: Angkasa. 